\title{
Bio-Control of Chamomile Powdery Mildew Using Cyanobacteria and Some Antagonistic Microorganisms
}

\author{
Ghebrial, E.W.R. ${ }^{1}$; El-Abeid, S.E. ${ }^{1}$ and Aref, E.M. ${ }^{2}$ \\ 1- Plant Pathology Research Institute, Agricultural Research \\ Center, Giza, Egypt. \\ 2- Soils, Water and Environment Research Institute, \\ Agricultural Research Center, Giza, Egypt.
}

Field experiments were carried out under natural infection in the - Experimental Farm of Sids Agricultural Research Station, Agric. Res. Center, Beni-Sweif governorate to evaluate the potentiality of Bacillus subtilis, Pseudomonas fluorescens, Trichoderma harzianum and cyanobacteria (Spirulina platensis) alone or in mixture to control powdery mildew on chamomile and its productivity using two application methods: soaking the seedling roots before transplanting + foliar spray and foliar spray only. Generally, all the tested bioagents were effective in reduction the disease incidence and severity leading to a significant increase in fresh and dry weights of the blossoms as well as essential oil percent and oil yield compared with the control treatment. Soaking the chamomile seedling roots and spraying the leaves with suspensions for bioagents tested were the most effective in reducing the disease incidence and severity than spraying the leaves by the suspensions only. Mixing the cyanobacteria ( $S$. platensis) with the fungal and bacterial antagonistics was more effective compared to each treatment separately. The highest efficacy was obtained from plots received mixed treatment of $S$. platensis $+P$. fluorescens in addition to the fungicide Topas 100 EC. Furthermore, all the treatments showed significant increases in the defence-related enzymes, peroxidase (PO) and polyphenoloxidase (PPO) as compared with the untreated control. Spirulina platensis significantly enhanced the growth of $T$. harzianum and did not show any inhibitory effect against bacterial growth as well as significantly increased the number of bacterial colony forming units (cfu) of $B$. subtilis and $P$. fluorescens which significantly improved the microbial status in the rhizosphere of chamomile plants.

Keywords: Powdery mildew, cyanobacteria, bioagents, defencerelated enzymes, peroxidase, polyphenoloxidase, productivity and chamomile.

German chamomile (Matricaria chamomilla L.) belonging to the Asteraceae family is one of the most commonly used medicinal plants all over the world (Mohammad, 2011). Nowadays, it is highly favored and widely used in the folk and traditional medicine (Srivastava et al., 2010 and Gosztola, 2012). One of the main 
reasons for the pharmaceutical characters of chamomile is related to different classes of active constituents, including the essential oil (Szoke et al. 2004). The plant contains $0.24-1.9 \%$ essential oil, from which over 120 secondary metabolites have been identified, such as chamazulene, $(-)$ - $\alpha$-bisabolol, apigenin and luteolin and many of these are pharmacologically active. Some of these compounds in the essential oil and the extracts are also used in perfumery and flavoring. The flower extract and essential oil possess anti-inflammatory, spasmolytic, carminative, antiseptic, sedative and ulcer protecting properties (Newall et al., 1996; Smitherman et al., 2005; Zaidi et al., 2012; Šavikin et al., 2013 and Zucchi et al., 2013).

Powdery mildew caused by Erysiphe cichoracearum is considered one of the most important diseases attacking chamomile plant in different cultivated areas in Egypt. Chamomile powdery mildew frequently occurs in the open field, estimated percentages of infection reach 20-80\% (El-Morsy and Shalaby, 2013). In severe infection, diseased plant seems as covered with a layer of talk powder and this causes great damage especially for flowers which are the important part of the plant, so the disease has negative effect on the quantity and quality of inflorescences yield, so all the possible procedures should be considered to manage it. The use of fungicides against plant diseases causes several problems such as carcinogenicity, development of fungicidal resistance populations of the pathogen and phytotoxicity as well as adverse effects of environmental balance (Pimentel et al., 1992 and Chen et al., 2007). Recently, increasing concerns for the production of chemical-free medicinal and aromatic plants has been the main goal of many researchers to find out environmentally safe strategies to control plant diseases in order to ensure the high quality and safety of the product. Thus, it is urgent to apply alternative safe efficient methods against plant diseases. Biological control received most of the attention because of their multiple modes of action to protect plants and their potential to be incorporated in integrated programs of management (Shoda, 2000 and Paulitz \& Bélanger, 2001). Powdery mildew has been successfully controlled by using algal, fungal and bacterial antagonists as reported by a number of researchers under greenhouse and field trials (Singh et al., 2000; El-Gamal, 2003; Deore et al., 2004 and Hegazi \& El-Kot, 2010). Bacillus subtilis, P. fluorescens and T. harzianum are a promising biocontrol agents provide protection or prevention against plant pathogens by competition for nutrients and space, antibiosis, production of lytic enzymes and induced host resistance through increased activity of many enzymes such as peroxidase and polyphenoloxidase which play a defense role against invading pathogens (Kohl and Fokkema, 1998; Hegazi \& El-Kot, 2010 and Roberti et al., 2016). In addition, they can produce some compounds which may act as plant growth promoters (Compant et al., 2005). Algae are one of the most potential biocontrol agents that have been studied for the control of plant pathogenic fungi (Hewedy et al., 2000). Cyanobacteria (blue-green algae) are able to produce a large variety of active secondary metabolites such as antibiotics, antifungal compounds and toxic activity and fix nitrogen (Skulberg, 2000). Abedin and Taha (2008) found

Egypt. J. Phytopathol., Vol. 47, No. 1 (2019) 
that $S$. platensis had antifungal activity towards the plant pathogenic fungi, increased growth parameters and yield in plants (Shalaby and El Ramady, 2014 and Jufri et al., 2016). The plant growth and essential oil content are highly affected by plant microbiome.

The present study was undertaken to evaluate the potential of B. subtilis, $P$. fluorescens, T. harzianum and cyanobacteria (Spirulina platensis) alone or in mixture to control powdery mildew on chamomile and its effect on the productivity using two application methods: seedling roots soaking and/or foliar spray under field conditions.

\section{Materials and Methods}

Bioagents used in experiments:

In experiments; four bio agents namely Bacillus subtilis, Pseudomonas fluorescens, Trichoderma harzianum and cyanobacteria (Spirulina platensis) were kindly obtained from Department of Microbiology, Soil, Water \& Environment Res. Inst., ARC, Giza, Egypt and used alone or in mixtures to evaluate their potential on E. cichoracearum spore germination, the effect of cyanobacteria (S. platensis) on the growth of the tested fungal and bacterial bioagents in vitro conditions as well as to control powdery mildew on chamomile and its effect on the productivity using two application methods: seedling roots soaking and/or foliar spray under field conditions.

Bacterial suspension was multiplied by cultivating $B$. subtilis in nutrient broth medium, while P. fluorescens in King B (KB) liquid medium (King et al., 1954) using shaking flask submerged culture, where $500 \mathrm{ml}$ conical flasks, each containing $200 \mathrm{ml}$ of the respective media was inoculated by one ml bacterial inoculum of $24 \mathrm{~h}$ old culture and incubated in rotary shaking incubator $(120 \mathrm{rpm})$ at $28 \pm 2^{\circ} \mathrm{C}$ for $48 \mathrm{~h}$. T. harzianum was grown in Trichoderma-selective medium broth (TSM) (Elad et al., 1981), amended with $300 \mathrm{mg} / \mathrm{l}$ streptomycin and $50 \mu \mathrm{g} \mathrm{ml}{ }^{-1}$ rose Bengal in conical flask, incubated at $25^{\circ} \mathrm{C}$ for 15 days. A cyanobacteria (S. platensis) was grown in Zarrouk medium for 1 month (Zarrouk, 1966) and applied at the rate of $50 \mathrm{~L} / \mathrm{fed}$.

In vitro assay:

Effect of bioagents on conidial germination:

Drops of the tested bioagent suspension either alone or in mixture were placed on glass slides and conidia of E. cichoracearum were directly lifted with the help of small paint brush from heavily infected chamomile leaves. The slides were then placed in moist chambers prepared by placing two moist filter papers in the inner surfaces of a Petri plate. Conidia immersed in distilled water as well as fungicide suspension (Topas $100 \mathrm{EC}$ ) were served as the control. Three replications were made for each treatment. The slides were incubated at $25 \pm 2^{\circ} \mathrm{C}$ for $24 \mathrm{~h}$ and the percent of germination was calculated under a light microscope (Abd-Alla, 2012). 
Effect of S. platensis on T. harzianum growth:

Dry S. platensis $(0.03 \mathrm{~g})$ was aseptically added to $100 \mathrm{ml}$ conical flasks containing $95 \mathrm{ml}$ sterilized PDA medium before solidifying and rotated gently to ensure equal distribution. Sterilized distilled water was added to flask to bring the total volume to $100 \mathrm{ml}$. Five milliliters of sterilized distilled water were added aseptically to the control flasks. The supplemented media were poured into sterilized Petri dishes $(9 \mathrm{~cm}$ diam.) approximately three plates, each containing $20 \mathrm{ml}$ of medium and then inoculated in the centre with a $5-\mathrm{mm}$ diameter mycelial disc of $T$. harzianum taken from the margin of 5-10 day old culture. The plates were incubated at $25^{\circ} \mathrm{C}$ in the dark. Fungal growth was recorded after the growth of any treatment reached the edge of the plate and the results expressed as the percentage of reduction or increase of radial growth in relation to the control.

Effect of S. platensis on bacterial growth:

Zone of growth inhibition technique was adopted according to Allen (1961). Conical flasks each containing $150 \mathrm{ml}$ of warm sterilized nutrient or King B agar medium were artificially seeded before solidification with $5 \mathrm{ml}$ of a $48 \mathrm{~h}$ old nutrient or King B broth of the tested bacteria, then poured into Petri dishes (three replicates). Wells (5 mm-diam.) were made up into solidified medium using sterilized cork borer. Equal volume $(0.1 \mathrm{ml})$ of the tested cyanobacteria was poured into each well. The same technique was also followed for control (without treatment). All Petri dishes were incubated at $25^{\circ} \mathrm{C}$ for $72 \mathrm{~h}$ then examined. Clear zone diameter of bacterial growth inhibition was measured and the inhibited growth area was measured.

The same plate count technique of Allen (1961) was used to determine the lethal dose of the tested cyanobacteria on bacteria. Amount of $0.03 \mathrm{~g}$ of the tested cyanobacteria was added to conical flasks containing sterilized nutrient or King B broth medium. Prepared flasks were individually inoculated with $1.0 \mathrm{ml}$ of the bacterial growth on the same medium for $48 \mathrm{~h}$ then incubated for $72 \mathrm{~h}$ at $25^{\circ} \mathrm{C}$. Serial dilutions $\left(10^{-1}\right.$ to $\left.10^{-7}\right)$, of each bacterial growth, were prepared. A volume of $1.0 \mathrm{ml}$ of final dilution of bacteria was poured into each Petri dish with $20 \mathrm{ml}$ of the corresponding agar medium. Petri dishes were then swirled gently to ensure an even distribution of bacteria into the medium. Three plates were used as replicates for each particular treatment and control as well. All plates were incubated at $25^{\circ} \mathrm{C}$ for $48 \mathrm{~h}$ then examined. Bacterial colonies were counted and the number of colony forming unites (cfu) per $1.0 \mathrm{ml}$ of bacterial suspension was calculated.

Field experiments:

A two-year field experiment was achieved under natural infection in the Experimental Farm of Sids Agricultural Research Station, Agric. Res. Center, BeniSweif governorate during the two growing seasons of 2017 and 2018 to evaluate the potential of Bacillus subtilis, Pseudomonas fluorescens, Trichoderma harzianum and cyanobacteria (Spirulina platensis) alone or in mixture to control powdery

Egypt. J. Phytopathol., Vol. 47, No. 1 (2019) 
mildew on chamomile and its effect on the productivity using two application methods: seedling roots soaking and/or foliar spray. The soil of the experimental field was clay in texture ( $16.5 \%$ sand, $30.1 \%$ silt, $53.4 \%$ clay), pH of 8.1 , EC 1.2 $\mathrm{dSm}^{-1} ; 1.3 \%$ organic matter and 26.2, 10.1 and $176 \mathrm{ppm}$ available $\mathrm{N}, \mathrm{P}$ and $\mathrm{K}$, respectively. The experiment was set in a randomized complete blocks design with two factors, three replications for each treatment. The first factor was assigned to the bioagents tested and the second one to application methods. The experimental plot was $6 \times 3.5 \mathrm{~m}^{2}$.

Chamomile seedling roots were soaked in the suspensions of each of Trichoderma isolate $\left(1 \times 10^{6}\right.$ conidia/ml $)$, B. subtilis, $P$. fluorescens $\left(3 \times 10^{8} \mathrm{cfu}\right)$ and $S$. platensis for $2 \mathrm{~h}$ before transplanting. The Chamomile seedlings were obtained from Sids Agricultural Research Station, Agric. Res. Center, Beni-Sweif governorate

In each season, the soil was mechanically plowed and planked twice. During the preparation for cultivation, calcium super-phosphate $\left(15.5 \% \mathrm{P}_{2} \mathrm{O}_{5}\right)$ as a source of phosphorus was added at the rate of $200 \mathrm{~kg} / \mathrm{fed}$. The treated and untreated seedlings, $15 \mathrm{~cm}$ length were transplanted at $30 \mathrm{~cm}$ spacing between plants on September, $15^{\text {th }}$ in the two experimental seasons. Weeds were removed by manual operations as needed and plants were irrigated regularly as necessary, throughout the growing season to maintain constant growth. Nitrogen was applied in the form of ammonium sulphate $(20.6 \% \mathrm{~N})$, at the rate of $400 \mathrm{~kg} / \mathrm{fed}$. (recommended rate) as follow: the first one $(100 \mathrm{~kg} / \mathrm{fed}$.) was added after one month from transplanting and the remainder amounts were added after each harvest. Potassium sulfate $\left(48 \% \mathrm{~K}_{2} \mathrm{O}\right)$ as a source of potassium was added at the rate of $75 \mathrm{~kg} / \mathrm{fed}$. The plants (40 days after transplanting) were sprayed every 10 days, always performed early in the morning, with the tested bioagents, $1 \%$ Tween 20 as well as the fungicide Topas 100 EC (Penconazole), Syngenta Co. at the rate of $25 \mathrm{~cm}^{3} / 100 \mathrm{~L}$ water before the appearance of first symptoms until run off. Monitoring and scouting the plants weekly for the appearance of powdery mildew and disease incidence and severity were estimated as follow:

Disease incidence:

Percentage of disease incidence was recorded as the number of diseased plants relative to the number of growing plants for each treatment, and then the average of disease incidence was calculated.

Disease severity:

Disease severity was measured using a scale of (0-4) according to Whitney et al. (1983), in which $0,1,2,3$, and 4 approximated $0,25,50,75$ and $100 \%$, respectively, of the matured leaf area covered by mildew. Percentage of disease severity was recorded according to the following equation:

Disease severity $\%=\left[\sum(\mathrm{n} \times \mathrm{c})\right] /(\mathrm{N} \times \mathrm{C}) \times 100$

Egypt. J. Phytopathol., Vol. 47, No. 1 (2019) 
Whereas: $\mathrm{n}=$ Number of infected leaves, $\mathrm{c}=$ Category number, $\mathrm{N}=$ Total number of examined leaves and $\mathrm{C}=$ The highest category number of infection.

The blossoms of the chamomile plant were harvested after 3 months from transplanting. The harvest was carried out every month and 4 harvests were collected during the season. The fresh and dry weights of blossoms were evaluated in all the treatments.

To determine the percentage of essential oil, $100 \mathrm{~g}$ dry blossoms representing each replicate were taken from the four harvests then subjected to steam distillation and determined according to Guenther (1961) and oil yield (kg/fed.) was determined.

Peroxidase activity was determined using the method described in the Worthington enzyme manual (Worthington, 1971). Polyphenoloxidase activity was measured following the method described by (Esterbaner et al., 1977). Analysis of enzymes was carried out at the Mycology and Disease Survey Res. Dept., Plant Pathol. Res. Inst., ARC.

Plant hormones (abscisic acid, gibberellic acid and indole acetic acid) were determined according to the method described by Shindy and Smith (1975). Carbon dioxide $\left(\mathrm{CO}_{2}\right)$ evolution was determined according to Gaur et al. (1971) at the Soil, Water \& Environment Res. Inst., ARC.

Statistical analysis:

Data were statistically analyzed for computing L.S.D. test at $5 \%$ probability according to the procedure outlined by Snedecor and Cochran (1989).

\section{Results}

Results in Table, 1 show that reduction in spore germination percent was significantly noticed with all bioagents tested each alone or in mixture and the highest reduction was exhibited in case of fungicide Topas $100 \mathrm{EC}$ and S. platensis $+P$. fluorescens treatments without significant differences between them, being 94.5 $\%$ reduction in spore germination followed by S. platensis $+B$. subtilis and $S$. platensis $+T$. harzianum treatments with averages of 92.6 and $89.4 \%$, respectively. Moreover, moderate reduction was observed with the bioagents $S$. platensis, $P$. fluorescens and B. subtilis each alone. The bioagent $T$. harzianum showed the lowest inhibitory effect towards spore germination.

Data presented in Table, 2 show the effect of S. platensis on the viability of both bacteria and growth of T. harzianum. S. platensis significantly enhanced the growth of $T$. harzianum and increased the colony diameter by $136.8 \%$ compared to the untreated control. On the other hand, S. platensis did not show any inhibitory effect against bacterial growth (Fig. 1). The numbers of bacterial colony forming units (cfu) were significantly increased by $67.0 \%$ for B. subtilis and $83.5 \%$ for $P$.

Egypt. J. Phytopathol., Vol. 47, No. 1 (2019) 
fluorescens when these bacteria were grown on each respective broth medium amended with $S$. platensis.

Table 1: Effect of different bioagents on spore germination of Erysiphe cichoracearum in vitro.

\begin{tabular}{|l|c|c|}
\hline \multicolumn{1}{|c|}{ Treatments } & Germination \% & Reduction $^{*} \%$ \\
\hline B. subtilis & 9.6 & 69.0 \\
\hline P. fluorescens & 7.0 & 77.4 \\
\hline S. platensis & 5.6 & 81.9 \\
\hline T. harzianum & 12.3 & 60.3 \\
\hline S. platensis + B. subtilis & 2.3 & 92.6 \\
\hline S. platensis + P. fluorescens & 1.7 & 94.5 \\
\hline S. platensis + T. harzianum & 3.3 & 89.4 \\
\hline Topas $100 \mathrm{EC}$ & 1.7 & 94.5 \\
\hline Control & 31.0 & --- \\
\hline L.S.D. at 0.05 & 1.6 & --- \\
\hline
\end{tabular}

* Reduction \% related to the control.

Table 2: Effect of $S$. platensis on linear growth of $\boldsymbol{T}$. harzianum and viability of $B$. subtilis and $P$. fluorescens in vitro.

\begin{tabular}{|c|c|c|c|c|c|c|}
\hline \multirow{3}{*}{ Treatments } & \multicolumn{2}{|c|}{$\begin{array}{c}\text { Mycelial linear } \\
\text { growth }\end{array}$} & \multicolumn{3}{c|}{ Total counts of viable cells } \\
\cline { 2 - 7 } & \multicolumn{2}{|c|}{ T. harzianum } & \multicolumn{2}{c|}{ B. subtilis } & \multicolumn{2}{c|}{ P. fluorescens } \\
\cline { 2 - 7 } & $\begin{array}{c}\text { Colony } \\
\text { diameter } \\
(\mathrm{mm})\end{array}$ & $\begin{array}{c}\text { Increase* } \\
(\%)\end{array}$ & $\begin{array}{c}\text { Total } \\
\text { counts } \\
\left(10^{7}\right. \\
\text { cfu/ml })\end{array}$ & $\begin{array}{c}\text { Increase* } \\
(\%)\end{array}$ & $\begin{array}{c}\text { Total } \\
\text { counts } \\
\left(10^{7}\right. \\
\text { cfu/ml })\end{array}$ & $\begin{array}{c}\text { Increase* } \\
(\%)\end{array}$ \\
\hline S. platensis & 90.0 & 136.8 & 811.5 & 67.0 & 790.3 & 83.5 \\
\hline Control & 38.0 & --- & 485.8 & --- & 430.6 & -- \\
\hline $\begin{array}{c}\text { L.S.D. at } \\
\text { 0.05 }\end{array}$ & 2.3 & --- & 77.0 & --- & 79.5 & --- \\
\hline
\end{tabular}

* Increase \% related to the control. 

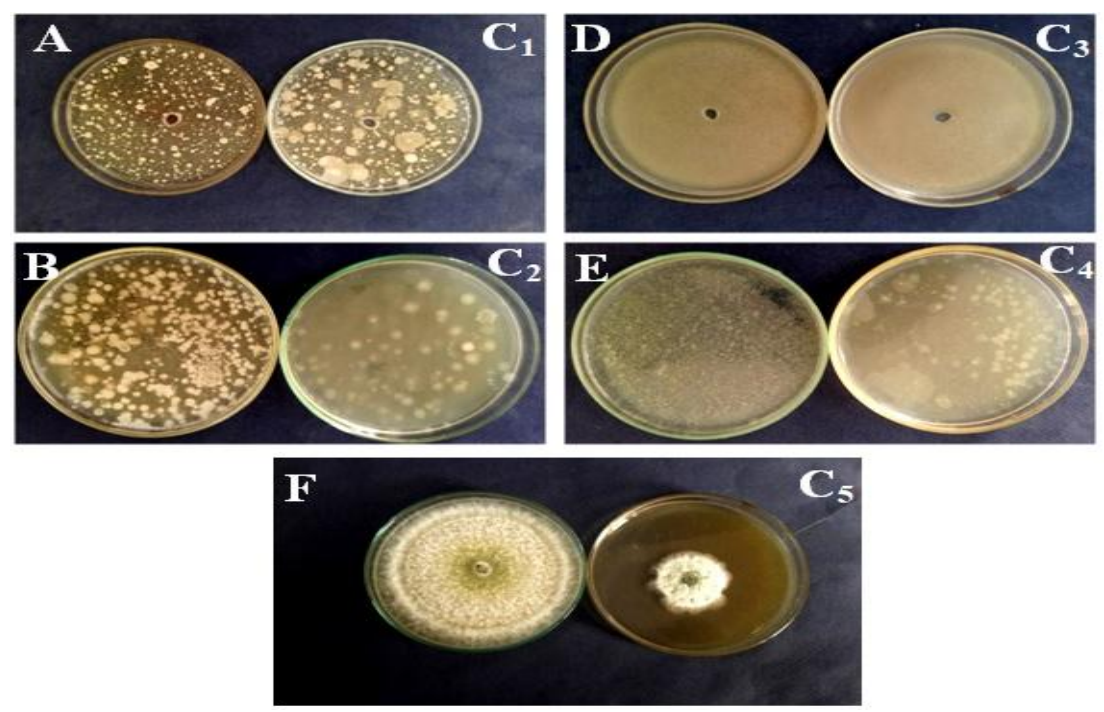

Fig. 1: Effect of $S$. platensis on inhibition zone (A), Total counts of viable cells $(B)$ of $B$. subtilis; inhibition zone (D), Total counts of viable cells (E) of $P$. fluorescens and growth of $T$. harzianum (F) compared with the untreated control $\left(\mathrm{C}_{1}, \mathrm{C}_{2}\right.$ for $B$. subtilis; $\mathrm{C}_{3}, \mathrm{C}_{4}$ for $P$. fluorescens; $\mathrm{C}_{5}$ for $T$. harzianum).

Data presented in Tables, 3 and 4 demonstrate that all the tested bioagents significantly reduced disease incidence and delayed the progress of chamomile powdery mildew when used individually or as mixtures compared with the untreated control during the two growing seasons under field conditions. In season 2017, the lowest disease incidence and severity, being 21.1 and $9.0 \%$, respectively were noticed in plots received the mixed treatment of $S$. platensis $+P$. fluorescens which statistically on a par with the fungicide Topas 100 EC (18.2 and $6.9 \%$, respectively). Treatment $B$. subtilis mixed with cyanobacteria (S. platensis) came in the second rank followed by $S$. platensis $+T$. harzianum treatment. The corresponding mean values of powdery mildew incidence in season 2017 were 35.4 and $45.9 \%$ and disease severity, 21.1 and $26.6 \%$, respectively. Moderate disease incidence and severity were observed in plots received $S$. platensis and $P$. fluorescens applied each alone followed by $B$. subtilis treatments, being 54.3, 57.5 and $71.9 \%$, respectively for disease incidence and 32.3, 35.2 and $39.6 \%$, respectively for disease severity during the season of 2017. Meanwhile, application of $T$. harzianum gave the highest disease severity compared with the bioagents tested. The same trend was noticed in the second growing season. In general, the effectiveness of the tested bioagents significantly varied according to the application method. Soaking the chamomile seedling roots and spraying the leaves with

Egypt. J. Phytopathol., Vol. 47, No. 1 (2019) 
bioagents suspensions was the most effective application method in reducing the disease incidence and severity than spraying the leaves by suspensions only.

The interaction between the tested bioagents and their application methods was significant during the two successive growing seasons. Application of the fungicide as seedling treatment and foliar spray was the most efficient treatment, maintaining powdery mildew incidence and severity at especially low levels (16.5 and $5.3 \%$, respectively) in the first growing season (2017) followed by treatment of soaking seedling roots and foliar spray with $S$. platensis $+P$. fluorescens $(18.7$ and $6.9 \%$, respectively) without significant differences between them. Meanwhile, the lowest efficient was $T$. harzianum treatment when applied as foliar spray only. The same trend was observed in the second growing season (2018).

Table 3: Effect of some biocontrol agents and the fungicide Topas $100 \mathrm{EC}$ on the incidence of powdery mildew on chamomile grown under field conditions during the two successive growing seasons 2017 and 2018.

\begin{tabular}{|c|c|c|c|c|c|c|}
\hline \multirow[b]{4}{*}{$\begin{array}{c}\text { Treatments } \\
\text { (T) }\end{array}$} & \multicolumn{6}{|c|}{ Disease incidence $\%$} \\
\hline & \multicolumn{6}{|c|}{ Application methods (M) } \\
\hline & \multicolumn{3}{|c|}{ Season of 2017} & \multicolumn{3}{|c|}{ Season of 2018} \\
\hline & $\begin{array}{c}\text { Soaking } \\
\text { seedling } \\
\text { roots + } \\
\text { foliar } \\
\text { spray }\end{array}$ & $\begin{array}{l}\text { Foliar } \\
\text { spray }\end{array}$ & Mean $(\mathrm{T})$ & $\begin{array}{c}\text { Soaking } \\
\text { seedling } \\
\text { roots } \\
+ \text { foliar } \\
\text { spray } \\
\end{array}$ & $\begin{array}{l}\text { Foliar } \\
\text { spray }\end{array}$ & Mean $(\mathrm{T})$ \\
\hline B. subtilis & 67.8 & 76.0 & 71.9 & 62.6 & 71.3 & 67.0 \\
\hline P. fluorescens & 53.4 & 61.6 & 57.5 & 49.0 & 53.5 & 51.3 \\
\hline S. platensis & 50.2 & 58.3 & 54.3 & 42.5 & 50.0 & 46.3 \\
\hline T. harzianum & 82.9 & 95.7 & 89.3 & 81.3 & 92.0 & 86.7 \\
\hline $\begin{array}{l}\text { S. platensis }+B . \\
\text { subtilis }\end{array}$ & 31.0 & 39.8 & 35.4 & 25.2 & 35.4 & 30.3 \\
\hline $\begin{array}{l}\text { S. platensis }+P . \\
\text { fluorescens }\end{array}$ & 18.7 & 23.4 & 21.1 & 11.4 & 18.6 & 15.0 \\
\hline $\begin{array}{l}\text { S. platensis }+T \text {. } \\
\text { harzianum }\end{array}$ & 40.5 & 51.2 & 45.9 & 33.6 & 48.6 & 41.1 \\
\hline Topas $100 \mathrm{EC}$ & 16.5 & 19.8 & 18.2 & 7.7 & 15.2 & 11.5 \\
\hline Control & 100.0 & 100.0 & 100.0 & 100.0 & 100.0 & 100.0 \\
\hline Mean (M) & 51.2 & 58.4 & --- & 45.9 & 53.8 & --- \\
\hline L.S.D. at 0.05 & $\mathrm{~T}=3.5$ & $M=1.7$ & $\Gamma \mathrm{M}=5.0$ & $\mathrm{~T}=2.9$ & {$[=1.4$} & $\mathrm{M}=4.2$ \\
\hline
\end{tabular}


Table 4: Effect of some biocontrol agents and the fungicide Topas $100 \mathrm{EC}$ on the severity of powdery mildew on chamomile grown under field conditions during the two successive growing seasons 2017 and 2018.

\begin{tabular}{|c|c|c|c|c|c|c|}
\hline \multirow{4}{*}{$\begin{array}{l}\text { Treatments } \\
\text { (T) }\end{array}$} & \multicolumn{6}{|c|}{ Disease severity $\%$} \\
\hline & \multicolumn{6}{|c|}{ Application methods (M) } \\
\hline & \multicolumn{3}{|c|}{ Season of 2017} & \multicolumn{3}{|c|}{ Season of 2018} \\
\hline & $\begin{array}{c}\text { Soaking } \\
\text { seedling } \\
\text { roots }+ \\
\text { foliar } \\
\text { spray } \\
\end{array}$ & $\begin{array}{l}\text { Foliar } \\
\text { spray }\end{array}$ & $\begin{array}{l}\text { Mean } \\
(\mathrm{T})\end{array}$ & $\begin{array}{l}\text { Soaking } \\
\text { seedling } \\
\text { roots } \\
+ \text { foliar } \\
\text { spray } \\
\end{array}$ & $\begin{array}{l}\text { Foliar } \\
\text { spray }\end{array}$ & $\begin{array}{l}\text { Mean } \\
(\mathrm{T})\end{array}$ \\
\hline B. subtilis & 37.1 & 42.0 & 39.6 & 35.3 & 40.5 & 37.9 \\
\hline P. fluorescens & 32.6 & 37.8 & 35.2 & 30.0 & 37.0 & 33.5 \\
\hline S. platensis & 30.0 & 34.6 & 32.3 & 27.6 & 32.1 & 29.9 \\
\hline T. harzianum & 54.5 & 64.1 & 59.3 & 53.3 & 63.3 & 58.3 \\
\hline $\begin{array}{l}\text { S. platensis }+B . \\
\text { subtilis }\end{array}$ & 17.8 & 24.3 & 21.1 & 14.3 & 22.3 & 18.3 \\
\hline $\begin{array}{l}\text { S. platensis }+P . \\
\text { fluorescens }\end{array}$ & 6.9 & 11.1 & 9.0 & 3.2 & 9.7 & 6.5 \\
\hline $\begin{array}{l}\text { S. platensis }+T . \\
\text { harzianum }\end{array}$ & 23.5 & 29.7 & 26.6 & 20.5 & 27.2 & 23.9 \\
\hline Topas 100 EC & 5.3 & 8.5 & 6.9 & 2.6 & 5.9 & 4.3 \\
\hline Control & 87.0 & 88.6 & 87.8 & 87.6 & 87.6 & 87.6 \\
\hline Mean $(\mathrm{M})$ & 32.7 & 37.9 & --- & 30.5 & 36.2 & --- \\
\hline L.S.D. at 0.05 & \multicolumn{3}{|l|}{$\mathrm{T}=2.2$} & \multicolumn{3}{|c|}{$\mathrm{T}=2.4 \quad \mathrm{M}=1.1 \quad \mathrm{TM}=3.4$} \\
\hline
\end{tabular}

Results show a general improvement in both vegetative and blossoms yield of chamomile. Fresh and dry weights of chamomile blossoms (Tables, 5 and 6) as well as oil percent and oil yield were influenced by the tested bioagent (Tables, 7 and 8). In 2017 growing season, the combination between $S$. platensis and $P$. fluorescens showed the highest blossoms fresh and dry weights, oil percentage and oil yield, being $3.67 \mathrm{ton} / \mathrm{fed}$., $731.1 \mathrm{~kg} / \mathrm{fed}$., $0.60 \%$ and $4.4 \mathrm{~kg} / \mathrm{fed}$., respectively followed by plots received a mixture treatment of $S$. platensis $+B$. subtilis. On the other hand, the lowest blossoms fresh and dry weights, oil percentage and oil yield were obtained from plots received $T$. harzianum, being 2.89 ton/fed.; $557.1 \mathrm{~kg} / \mathrm{fed}$., 0.24 $\%$ and $1.3 \mathrm{~kg} / \mathrm{fed}$., respectively. The fresh and dry weight, oil \% and oil yield values were 2.78 ton/fed.; $429.3 \mathrm{~kg} / \mathrm{fed} ., 0.21 \%$ and $0.9 \mathrm{~kg} / \mathrm{fed}$., respectively in control Egypt. J. Phytopathol., Vol. 47, No. 1 (2019) 
plants. The same trend was also true for 2018 growing season. Overall, the improvement in both vegetative and blossoms yield of chamomile was significant regarding roots soaking + spraying the leaves with the tested bioagents method over foliar spray method only.

Table 5: Effect of some biocontrol agents and the fungicide Topas $100 \mathrm{EC}$ on fresh weight of chamomile blossoms (ton/fed.) grown under field conditions during the two successive growing seasons 2017 and 2018.

\begin{tabular}{|c|c|c|c|c|c|c|}
\hline \multirow{4}{*}{$\begin{array}{l}\text { Treatments } \\
\text { (T) }\end{array}$} & \multicolumn{6}{|c|}{ Fresh weight of blossoms (ton/fed.) } \\
\hline & \multicolumn{6}{|c|}{ Application methods (M) } \\
\hline & \multicolumn{3}{|c|}{ Season of 2017} & \multicolumn{3}{|c|}{ Season of 2018} \\
\hline & $\begin{array}{c}\text { Soaking } \\
\text { seedling } \\
\text { roots + } \\
\text { foliar } \\
\text { spray } \\
\end{array}$ & $\begin{array}{l}\text { Foliar } \\
\text { spray }\end{array}$ & $\begin{array}{l}\text { Mean } \\
(\mathrm{T})\end{array}$ & $\begin{array}{c}\text { Soaking } \\
\text { seedling } \\
\text { roots + } \\
\text { foliar } \\
\text { spray } \\
\end{array}$ & $\begin{array}{l}\text { Foliar } \\
\text { spray }\end{array}$ & $\begin{array}{l}\text { Mean } \\
(\mathrm{T})\end{array}$ \\
\hline B. subtilis & 3.18 & 2.95 & 3.07 & 3.29 & 3.06 & 3.18 \\
\hline P. fluorescens & 3.20 & 3.00 & 3.10 & 3.35 & 3.10 & 3.23 \\
\hline S. platensis & 3.45 & 3.27 & 3.36 & 3.69 & 3.36 & 3.53 \\
\hline T. harzianum & 3.03 & 2.75 & 2.89 & 3.08 & 2.89 & 2.99 \\
\hline $\begin{array}{l}\text { S. platensis }+B . \\
\text { subtilis }\end{array}$ & 3.69 & 3.47 & 3.58 & 3.85 & 3.49 & 3.67 \\
\hline $\begin{array}{l}\text { S. platensis }+P \text {. } \\
\text { fluorescens }\end{array}$ & 3.82 & 3.52 & 3.67 & 3.95 & 3.58 & 3.77 \\
\hline $\begin{array}{l}\text { S. platensis }+T \text {. } \\
\text { harzianum }\end{array}$ & 3.54 & 3.30 & 3.42 & 3.81 & 3.35 & 3.58 \\
\hline Topas 100 EC & 3.16 & 2.84 & 3.00 & 3.12 & 2.90 & 3.01 \\
\hline Control & 2.81 & 2.74 & 2.78 & 2.53 & 2.64 & 2.59 \\
\hline Mean (M) & 3.32 & 3.09 & --- & 3.41 & 3.15 & --- \\
\hline L.S.D. at 0.05 & \multicolumn{3}{|l|}{$\mathrm{T}=0.17$} & \multicolumn{3}{|c|}{$\mathrm{T}=0.21 \quad \mathrm{M}=0.10 \quad \mathrm{TM}=0.29$} \\
\hline
\end{tabular}

The interaction between bioagents tested and application methods had significant effect on fresh and dry weights of chamomile blossoms as well as oil percentage and oil yields. In 2017 growing season, the maximum values of these parameters were obtained from plots received chamomile seedling roots previously soaked in a mixture of $S$. platensis $+P$. fluorescens and spraying the leaves with their suspensions (3.82 ton/fed.; $779.3 \mathrm{~kg} / \mathrm{fed} ., 0.62 \%$ and $4.8 \mathrm{~kg} / \mathrm{fed}$., respectively), 
while the lowest blossoms fresh and dry weights, oil \% and oil yields ( 2.75 ton/fed.; $534.9 \mathrm{~kg} / \mathrm{fed}$., $0.22 \%$ and $1.2 \mathrm{~kg} /$ fed., respectively) was obtained from plots received $T$. harzianum as foliar spray only. The same trend was observed in the second season (2018).

Table 6: Effect of some biocontrol agents and the fungicide Topas $100 \mathrm{EC}$ on dry weight of chamomile blossoms $(\mathrm{kg} / \mathrm{fed}$.) grown under field conditions during the two successive growing seasons 2017 and 2018.

\begin{tabular}{|c|c|c|c|c|c|c|}
\hline \multirow{4}{*}{$\begin{array}{l}\text { Treatments } \\
\text { (T) }\end{array}$} & \multicolumn{6}{|c|}{ Dry weight of blossoms (kg/fed.) } \\
\hline & \multicolumn{6}{|c|}{ Application methods (M) } \\
\hline & \multicolumn{3}{|c|}{ Season of 2017} & \multicolumn{3}{|c|}{ Season of 2018} \\
\hline & $\begin{array}{c}\text { Soaking } \\
\text { seedling } \\
\text { roots + } \\
\text { foliar } \\
\text { spray } \\
\end{array}$ & $\begin{array}{l}\text { Foliar } \\
\text { spray }\end{array}$ & $\begin{array}{l}\text { Mean } \\
(\mathrm{T})\end{array}$ & $\begin{array}{c}\text { Soaking } \\
\text { seedling } \\
\text { roots }+ \\
\text { foliar } \\
\text { spray }\end{array}$ & $\begin{array}{l}\text { Foliar } \\
\text { spray }\end{array}$ & $\begin{array}{l}\text { Mean } \\
(\mathrm{T})\end{array}$ \\
\hline B. subtilis & 643.4 & 588.5 & 616.0 & 653.0 & 603.7 & 628.4 \\
\hline P. fluorescens & 655.6 & 591.0 & 623.3 & 665.9 & 611.8 & 638.9 \\
\hline S. platensis & 703.8 & 624.4 & 664.1 & 715.9 & 631.8 & 673.9 \\
\hline T. harzianum & 579.3 & 534.9 & 557.1 & 589.6 & 541.5 & 565.6 \\
\hline $\begin{array}{l}\text { S. platensis }+B \text {. } \\
\text { subtilis }\end{array}$ & 749.1 & 635.4 & 692.3 & 770.0 & 695.6 & 732.8 \\
\hline $\begin{array}{l}\text { S. platensis }+P \text {. } \\
\text { fluorescens }\end{array}$ & 779.3 & 682.9 & 731.1 & 790.3 & 716.0 & 753.2 \\
\hline $\begin{array}{l}\text { S. platensis }+T \text {. } \\
\text { harzianum }\end{array}$ & 718.6 & 643.8 & 681.2 & 756.8 & 644.3 & 700.6 \\
\hline Topas $100 \mathrm{EC}$ & 590.5 & 544.4 & 567.5 & 620.7 & 554.6 & 587.7 \\
\hline Control & 428.6 & 430.0 & 429.3 & 444.5 & 428.6 & 436.6 \\
\hline Mean (M) & 649.8 & 586.1 & --- & 667.4 & 603.1 & --- \\
\hline L.S.D. at 0.05 & $\mathrm{~T}=13.5$ & $M=6.4$ & $\Gamma \mathrm{M}=19.1$ & $\mathrm{~T}=11.2$ & $\mathrm{M}=5.3$ & $\mathrm{TM}=15.9$ \\
\hline
\end{tabular}

Egypt. J. Phytopathol., Vol. 47, No. 1 (2019) 
Table 7: Effect of some biocontrol agents and the fungicide Topas $100 \mathrm{EC}$ on oil $\%$ of chamomile blossoms grown under field conditions during the two successive growing seasons 2017 and 2018.

\begin{tabular}{|c|c|c|c|c|c|c|}
\hline \multirow{4}{*}{$\begin{array}{l}\text { Treatments } \\
\text { (T) }\end{array}$} & \multicolumn{6}{|c|}{ oil \% } \\
\hline & \multicolumn{6}{|c|}{ Application methods (M) } \\
\hline & \multicolumn{3}{|c|}{ Season of 2017} & \multicolumn{3}{|c|}{ Season of 2018} \\
\hline & $\begin{array}{l}\text { Soaking } \\
\text { seedling } \\
\text { roots } \\
+ \text { foliar } \\
\text { spray } \\
\end{array}$ & $\begin{array}{l}\text { Foliar } \\
\text { spray }\end{array}$ & $\begin{array}{l}\text { Mean } \\
(\mathrm{T})\end{array}$ & $\begin{array}{l}\text { Soaking } \\
\text { seedling } \\
\text { roots } \\
+ \text { foliar } \\
\text { spray }\end{array}$ & $\begin{array}{l}\text { Foliar } \\
\text { spray }\end{array}$ & $\begin{array}{l}\text { Mean } \\
(\mathrm{T})\end{array}$ \\
\hline B. subtilis & 0.30 & 0.26 & 0.28 & 0.31 & 0.27 & 0.29 \\
\hline P. fluorescens & 0.32 & 0.30 & 0.31 & 0.32 & 0.32 & 0.32 \\
\hline S. platensis & 0.34 & 0.32 & 0.33 & 0.36 & 0.31 & 0.34 \\
\hline T. harzianum & 0.25 & 0.22 & 0.24 & 0.24 & 0.22 & 0.23 \\
\hline $\begin{array}{l}\text { S. platensis }+B . \\
\text { subtilis }\end{array}$ & 0.58 & 0.40 & 0.49 & 0.57 & 0.42 & 0.50 \\
\hline $\begin{array}{l}\text { S. platensis }+P . \\
\text { fluorescens }\end{array}$ & 0.62 & 0.58 & 0.60 & 0.62 & 0.57 & 0.60 \\
\hline $\begin{array}{l}\text { S. platensis }+T \text {. } \\
\text { harzianum }\end{array}$ & 0.36 & 0.34 & 0.35 & 0.37 & 0.34 & 0.36 \\
\hline Topas 100 EC & 0.28 & 0.25 & 0.27 & 0.29 & 0.27 & 0.28 \\
\hline Control & 0.21 & 0.20 & 0.21 & 0.22 & 0.22 & 0.22 \\
\hline Mean (M) & 0.36 & 0.32 & --- & 0.37 & 0.33 & --- \\
\hline L.S.D. at 0.05 & $\mathrm{~T}=0.01$ & $\mathrm{M}=0.01$ & $M=0.02$ & $\mathrm{~T}=0.01$ & $\mathrm{M}=0.01$ & $M=0.02$ \\
\hline
\end{tabular}


Table 8: Effect of some biocontrol agents and the fungicide Topas $100 \mathrm{EC}$ on oil yield ( $\mathrm{kg} / \mathrm{fed}$.) of chamomile grown under field conditions during the two successive growing seasons 2017 and 2018.

\begin{tabular}{|c|c|c|c|c|c|c|}
\hline \multirow[b]{4}{*}{$\begin{array}{l}\text { Treatments } \\
\text { (T) }\end{array}$} & \multicolumn{6}{|c|}{ Oil yield (kg/fed) } \\
\hline & \multicolumn{6}{|c|}{ Application methods (M) } \\
\hline & \multicolumn{3}{|c|}{ Season of 2017} & \multicolumn{3}{|c|}{ Season of 2018} \\
\hline & $\begin{array}{l}\text { Soaking } \\
\text { seedling } \\
\text { roots } \\
+ \text { foliar } \\
\text { spray } \\
\end{array}$ & $\begin{array}{l}\text { Foliar } \\
\text { spray }\end{array}$ & $\begin{array}{l}\text { Mean } \\
(\mathrm{T})\end{array}$ & $\begin{array}{c}\text { Soaking } \\
\text { seedling } \\
\text { roots } \\
+ \text { foliar } \\
\text { spray } \\
\end{array}$ & $\begin{array}{l}\text { Foliar } \\
\text { spray }\end{array}$ & $\begin{array}{l}\text { Mean } \\
(\mathrm{T})\end{array}$ \\
\hline B. subtilis & 1.9 & 1.5 & 1.7 & 2.0 & 1.6 & 1.8 \\
\hline P. fluorescens & 2.1 & 1.8 & 2.0 & 2.1 & 2.0 & 2.1 \\
\hline S. platensis & 2.4 & 2.0 & 2.2 & 2.6 & 2.0 & 2.3 \\
\hline T. harzianum & 1.4 & 1.2 & 1.3 & 1.4 & 1.2 & 1.3 \\
\hline $\begin{array}{l}\text { S. platensis }+B . \\
\text { subtilis }\end{array}$ & 4.3 & 2.5 & 3.4 & 4.4 & 2.9 & 3.7 \\
\hline $\begin{array}{l}\text { S. platensis }+P \text {. } \\
\text { fluorescens }\end{array}$ & 4.8 & 4.0 & 4.4 & 4.9 & 4.1 & 4.5 \\
\hline $\begin{array}{l}\text { S. platensis }+T \text {. } \\
\text { harzianum }\end{array}$ & 2.6 & 2.2 & 2.4 & 2.8 & 2.2 & 2.5 \\
\hline Topas 100 EC & 1.7 & 1.4 & 1.6 & 1.8 & 1.5 & 1.7 \\
\hline Control & 0.9 & 0.9 & 0.9 & 1.0 & 0.9 & 1.0 \\
\hline Mean (M) & 2.5 & 1.9 & --- & 2.6 & 2.0 & --- \\
\hline L.S.D. at 0.05 & $\mathrm{~T}=0.2$ & $\mathrm{M}=0.1$ & $M=0.3$ & $\mathrm{~T}=0.3$ & $M=0.1$ & $M=0.4$ \\
\hline
\end{tabular}

Data presented in Table, 9 show the effect of the tested bioagents on the activity of defense related enzymes in the treated chamomile plants compared with the control. Overall, all tested bioagents and fungicide Topas 100 EC significantly increased the activity of defense related enzymes. Mixing the fungal and bacterial antagonistic agents with the cyanobacteria (S. platensis) resulted excess in the activity for both peroxidase and polyphenoloxidase enzymes compared to the treatment separately. Maximum increase in peroxidase and polyphenoloxidase activities was detected due to using $S$. platensis mixed with $P$. fluorescens, being 1.528 and 0.144 , respectively followed by treatments of $S$. platensis mixed with $B$. subtilis and T. harzianum. The lowest activity of these enzymes was detected in chamomile plants treated with $T$. harzianum. Soaking the chamomile seedling roots and spraying the leaves with bioagents suspensions significantly increased the activities of peroxidase and polyphenoloxidase compared to spraying the leaves by

Egypt. J. Phytopathol., Vol. 47, No. 1 (2019) 
any suspension only. Bioagents tested and application method interaction was found to be significant. Soaking the chamomile seedling roots in a mixture of S. platensis + $P$. fluorescens and spraying the leaves with their suspensions showed the highest peroxidase and polyphenoloxidase activities (1.536 and 0.195, respectively) while plants sprayed with $T$. harzianum only showed the lowest activities, being 0.585 and 0.051 , respectively.

Table 9: Enzyme activities in chamomile plants treated by different bioagents.

\begin{tabular}{|c|c|c|c|c|c|c|}
\hline \multirow{4}{*}{$\begin{array}{l}\text { Treatments } \\
\text { (T) }\end{array}$} & \multicolumn{6}{|c|}{ Enzymatic activities } \\
\hline & \multicolumn{6}{|c|}{ Application methods (M) } \\
\hline & \multicolumn{3}{|c|}{ Peroxidase } & \multicolumn{3}{|c|}{ Polyphenoloxidase } \\
\hline & $\begin{array}{c}\text { Soaking } \\
\text { seedling } \\
\text { roots } \\
+ \text { foliar } \\
\text { spray }\end{array}$ & $\begin{array}{l}\text { Foliar } \\
\text { spray }\end{array}$ & $\begin{array}{c}\text { Mean } \\
(\mathrm{T})\end{array}$ & $\begin{array}{c}\text { Soaking } \\
\text { seedling } \\
\text { roots } \\
+ \text { foliar } \\
\text { spray } \\
\end{array}$ & $\begin{array}{l}\text { Foliar } \\
\text { spray }\end{array}$ & Mean $(\mathrm{T})$ \\
\hline B. subtilis & 0.994 & 0.794 & 0.894 & 0.056 & 0.054 & 0.055 \\
\hline P. fluorescens & 1.117 & 0.736 & 0.927 & 0.061 & 0.059 & 0.060 \\
\hline S. platensis & 1.235 & 0.814 & 1.025 & 0.068 & 0.069 & 0.069 \\
\hline T. harzianum & 0.610 & 0.585 & 0.598 & 0.052 & 0.051 & 0.052 \\
\hline $\begin{array}{l}\text { S. platensis }+B . \\
\text { subtilis }\end{array}$ & 1.462 & 0.853 & 1.158 & 0.111 & 0.071 & 0.091 \\
\hline $\begin{array}{l}\text { S. platensis }+P \text {. } \\
\text { fluorescens }\end{array}$ & 1.536 & 1.520 & 1.528 & 0.195 & 0.093 & 0.144 \\
\hline $\begin{array}{l}\text { S. platensis }+T \text {. } \\
\text { harzianum }\end{array}$ & 1.238 & 0.830 & 1.034 & 0.084 & 0.073 & 0.079 \\
\hline Topas $100 \mathrm{EC}$ & 0.848 & 0.715 & 0.782 & 0.059 & 0.045 & 0.052 \\
\hline Control & 0.392 & 0.285 & 0.339 & 0.043 & 0.033 & 0.038 \\
\hline Mean (M) & 1.048 & 0.792 & --- & 0.081 & 0.061 & --- \\
\hline L.S.D. at 0.05 & $\mathrm{~T}=0.06$ & $I=0.03$ & $\mathrm{M}=0.0$ & $=0.005$ & $=0.00$ & $\Gamma \mathrm{M}=0.008$ \\
\hline
\end{tabular}

Data presented in Table, 10 show the capabilities of the tested bioagents to produce phytohormones. In this regard, S. platensis produced gibberellic acid (GA3) and indole acetic acid (IAA) much higher than the other bioagents tested followed by $P$. fluorescens, $B$. subtilis and T. harzianum. On the other hand, P. fluorescens produced abscisic acid (ABA) higher than B. subtilis and T. harzianum while $S$. platensis showed no production of abscisic acid. 
Table 10: Production of plant growth promoters by the tested bioagents.

\begin{tabular}{|c|c|c|c|}
\hline Bioagents & $\begin{array}{c}\text { Abscisic acid } \\
(\mathrm{ABA})(\mu \mathrm{g} / \mathrm{ml})\end{array}$ & $\begin{array}{c}\text { Gibberellic acid } \\
(\mathrm{GA} 3)(\mu \mathrm{g} / \mathrm{ml})\end{array}$ & $\begin{array}{c}\text { Indole acetic acid } \\
(\mathrm{IAA})(\mu \mathrm{g} / \mathrm{ml})\end{array}$ \\
\hline B. subtilis & 0.55 & 1.92 & 0.70 \\
\hline P. fluorescens & 0.63 & 3.02 & 0.72 \\
\hline S. platensis & 0.000 & 76.74 & 35.00 \\
\hline T. harzianum & 0.34 & 1.50 & 0.68 \\
\hline L.S.D. at 0.05 & 0.05 & 0.18 & 0.08 \\
\hline
\end{tabular}

It is clear that all treatments tested significantly improved the microbial status in the rhizosphere of chamomile plants as expressed as $\mathrm{CO}_{2}$ evolution (Table, 11). Mixing the cyanobacteria (S. platensis) with the fungal and bacterial antagonistic agents significantly increased the $\mathrm{CO}_{2}$ production compared to the treatment separately. In this regard, mixing $S$. platensis with $P$. fluorescens exhibited the superiority in rhizosphere microbial activity among all biological treatments which gave maximum value $(737.0 \mathrm{mg} / 100 \mathrm{~g}$ soil) followed by treatments of $S$. platensis mixed with $B$. subtilis and T. harzianum which produced $682.0 \mathrm{mg} / 100 \mathrm{~g}$ soil. While chemical fungicide treatment was the least among all treatments.

\section{Table 11: Evolution of $\mathrm{CO}_{2}$ in the rhizosphere of chamomile plant.}

\begin{tabular}{|l|c|}
\hline \multicolumn{1}{|c|}{ Treatments } & $\mathrm{CO}_{2}$ Mean of the two growing seasons \\
\hline B. subtilis & 572.0 \\
\hline P. fluorescens & 605.0 \\
\hline S. platensis & 627.0 \\
\hline T. harzianum & 517.0 \\
\hline S. platensis + B. subtilis & 682.0 \\
\hline S. platensis + P. fluorescens & 737.0 \\
\hline S. platensis + T. harzianum & 682.0 \\
\hline Topas 100 EC & 379.0 \\
\hline Control & 412.5 \\
\hline L.S.D. at 0.05 & 26.9 \\
\hline
\end{tabular}

\section{D is c us sion}

Application of biological control using antagonistic microorganisms has proved to be successful for controlling various plant diseases (O'Brien, 2017). Results of the present study demonstrated that all the tested bioagents significantly caused different degrees of suppression of the causal pathogen of chamomile powdery mildew compared to the control. Mixed treatment between the cyanobacteria $(S$. platensis) and the bacteria ( $P$. fluorescens) showed the highest efficacy in this concern. This result is in line with the report of Hussien et al. (2009) who found that application of $S$. platensis filtrate at concentration of 30 and $40 \%$ completely inhibited mycelium growth and spore production of Cercospora beticola. They Egypt. J. Phytopathol., Vol. 47, No. 1 (2019) 
concluded that the antifungal activity of the algal culture filtrates has been attributed to the presence of bioactive compounds, i.e. total phenolic compounds, total saponins, and alkaloids in the algal culture filtrates. The inhibition mechanisms are related to the disruption of the cell membrane integrity in spores and newly formed germ tubes. Florescent Pseudomonas is able to suppress diseases by producing protease, glucanase enzymes, in addition to enhancement the induced systemic resistance (Ko et al., 2009). Bacillus subtilis can inhibit fungal pathogens directly through the production of antifungal compounds from the iturin and fengycin families of lipopeptides which are able to repress spore germination (Bélanger et al., 1998 and Romero et al., 2007). Raaijmakers et al. (2002) concluded that the presence of bacterial cells in close relation to visibly collapsed conidia and hyphae suggests the local secretion of antifungal substances at sufficient concentrations to induce structural damage, resulting in the concomitant inhibition of spore germination and vegetative growth. Besides the direct inhibition, it also can induce resistance to foliar pathogens when applied to the plant root (Ongena et al., 2005a, b). Such induction of enhanced defensive capacity can be systemic as seed-treatment with bacteria at the time of seeding was shown to trigger protective effects on aboveground parts (Van Loon et al., 1998). Bacillus sp. has a great ability to colonize the rhizosphere of plants due to several physiological properties including its multilayered cell wall, formation of stress resistant endospore and antibiotic secretion provide these species with high advantage to survive for long periods of time under various environmental conditions. Application of T. harzianum T39 to the soil instead of spray reduced the powdery mildew coverage on the leaves by 75 to $90 \%$ (Elad et al., 1998). The mode of action was mainly the induced resistance. Disease reduction was accompanied with a gradual increase in peroxidase and polyphenoloxidase activity during the experimental period. In the present study, soaking the chamomile seedling roots and spraying the leaves with the tested bioagent suspension significantly induced synthesis and accumulation of PO, PPO than spraying the leaves by the suspensions alone. Generally, mixing the bioagents especially when $S$. platensis was mixed with $P$. fluorescens resulted excess in the activity for both enzymes compared to any treatment separately. This result is in line with Anand et al. (2007) and El-Ghanam et al. (2015) who recorded that a maximum increase in peroxidase and polyphenoloxidase activity was detected with $S$. platensis and P. fluorescens, resulted in remarkable increase in disease reduction. Polyphenoloxidase is the main enzyme that can oxidize the phenolic substance to quinoid substance, which gives effect to sterilize or inhibit the reproduction of pathogen (Handelsman \& Stabb, 1996 and Hammerschmidt, 1999). Peroxidase is a key enzyme in the biosynthesis of lignin and other oxidized phenols. It catalyzes the oxidation of hydroxy cinnamyl alcohols into free radical intermediates, which subsequently are coupled into lignin polymers. Besides, peroxidase itself was found to inhibit the spore germination and mycelial growth of certain fungi (Joseph et al., 1998 and Anand et al., 2007). 
Results of this study showed a general improvement in both vegetative and blossoms yield of chamomile as well as oil yield. These results are in the same direction with those of Aly et al. (2008) and Ali and Mostafa (2009). This increase could be attributed to the fact that $S$. platensis contains protein, $62 \%$ amino acid, minerals and it contains also the whole spectrum of mixed natural carotene and xanthophyl phytopigments which are considered as a rich natural source of vitamin B-12, phytohormones and antioxidants (Kemka et al., 2007). Chemical analysis of $S$. platensis as bio-stimulator revealed that it contains $6.7 \% \mathrm{~N}, 2.47 \% \mathrm{P}$ and $2.14 \% \mathrm{~K}$ as well as adequate amounts of micro elements needed for plant nutrition (Aly and Esawy, 2008). In addition, the available form of ammonia necessary for plant growth can be supplied by most cyanobacteria which can fix the atmospheric nitrogen into an available form of ammonia and thus can be used as bio-fertilizer (Vaishampayan et al., 2001). Pseudomonas spp. affect plant growth directly by producing and releasing secondary metabolites (plant growth regulators, phytohormones and biologically active substances), facilitating the availability and uptake of certain nutrients from the root environment. Pseudomonas fluorescens produces higher amounts of gibberellic acid (GA3) which is responsible for stem elongation and flowering process; mild amounts of indole acetic acid (IAA) which has an important role in the cell elongation and Abscesic acid (ABA) which has an important role in the adaptation of plants under stress conditions such as salinity, drought and low temperature (Bano et al., 2016). This could explain the positive impact of $P$. fluorescens and algae on the fresh and dry blossom yield of chamomile. Bacillus sp. has been reported to have mechanisms to promote plant growth by phytohormones production, mineralization and mobilization of phosphorus, siderophore production (Gutierrez-Manero et al., 2001; Whipps, 2001; Idris et al., 2007 and Richardson et al., 2009). The study demonstrated that all treatments tested significantly improved the microbial status in rhizosphere of chamomile plants. Mixing the cyanobacteria ( $S$. platensis) with the fungal and bacterial antagonistic agents significantly increased the $\mathrm{CO}_{2}$ production compared to any treatment separately. In this regard, mixing $S$. platensis with $P$. fluorescens exhibited the superiority in rhizosphere microbial activity among all biological treatments which gave maximum value of $\mathrm{CO}_{2}$ production followed by treatments of $S$. platensis mixed with $B$. subtilis and T. harzianum. While chemical fungicide treatment was the least among all treatments. This could be attributed to the harmful effect of chemical fungicide to other living organisms and reduce useful soil microorganisms as reported by Khalifa et al. (1995) and Lewis et al., (1996). This finding, is in agreement with those reported by Mahmoud et al. (2007) and El-Gabry et al. (2015). Spirulina platensis significantly enhanced the growth of $T$. harzianum and did not show any inhibitory effect against bacterial growth as well as significantly increased the numbers of bacterial colony forming units (cfu) of B. subtilis and P. fluorescens as noticed in the present study. This indicated that cyanobacteria ( $S$. platensis) are capable of increasing the population of the fungal and bacterial antagonistic agents and hence improve the microbial status in rhizosphere and phylloplane of plants as Egypt. J. Phytopathol., Vol. 47, No. 1 (2019) 
expressed by increasing the $\mathrm{CO}_{2}$ production and consequently, increasing the bioagent capability of these antagonistic microorganisms. Our results coincide with those obtained with El-Mougy and Abdel-Kader (2013). However, strain of $P$. fluorescens which is the more active plant growth promoting rhizobacteria in their high energy of metabolism reflecting the high productivity of $\mathrm{CO}_{2}$ in the rhizosphere. The production of $\mathrm{CO}_{2}$ led to formation of carbonic acid that decreases the soil $\mathrm{pH}$ value at rhizosphere. This process had done by rhizosphere microorganism's which act to increase nutrient uptake and availability of the nutrient in the rhizosphere plant area which in turn supported higher plant growth and yield. These results are in agreement with those reported by Seied et al. (2013) who indicated that the high $\mathrm{CO}_{2}$ production rates reflect the high energy of metabolism.

\section{Conclusion}

Cyanobacteria ( $S$. platensis) and bacteria ( $P$. fluorescens) showed a good potential to control powdery mildew of chamomile and improve the growth and yield of blossoms as well as oil yield. Therefore, it is recommended to use of soaking the seedling roots and foliar spraying with $S$. platensis mixed with $P$. fluorescens as safe biocontrol agents compared with the fungicide for controlling powdery mildew of chamomile and increasing its productivity under field conditions.

\section{References}

Abd-Alla, F.M.F. 2012. Studies on Powdery Mildew Disease Affecting Pea Plants in Egypt. Ph.D.Thesis, Fac. Agric., Cairo Univ., Cairo, 122 pp.

Abedin, R.M.A. and Taha, H.M. 2008. Antibacterial and antifungal activity of cyanobacteria and green microalgae. Evaluation of medium components by Placket-Burman design for antimicrobial activity of Spirulina platensis. Global J. biotechnol. \& biochem., 3(1) : 22 -31.

Ali, Lila K.M. and Mostafa, Soha S.M. 2009. Evaluation of potassium humate and Spirulina platensis as bioorganic fertilizer for sesame plants grown under salinity stress. Egypt. J. Agric. Res., 87(1): 369-388.

Allen, O.N., 1961. Experiments on Soil Bacteriology. Burgess Publishing Co., Minnesota, USA. 214 pp.

Aly, M.H.A.; Abd El-All, A.A.M. and Mostafa, S.S.M. 2008. Enhancement of sugar beet seed germination, plant growth, performance and biochemical compounds as contributed by algal extracellular products. J. Agric. Sci., Mansoura Univ., 33(12): 8429-8448.

Aly, M.S. and Esawy. M.A. 2008. Evaluation of Spirulina platensis as bio stimulator for organic farming systems. J. Gen. Eng. Biotechnol., 6:1-7.

Anand, T.; Chandrasekaran, A.; Kuttalam, S.; Raguchander, T.; Prakasam, V. and Samiyappan, R. 2007. Association of some plant defense enzyme activities

Egypt. J. Phytopathol., Vol. 47, No. 1 (2019) 
with systemic resistance to early leaf blight and leaf spot induced in tomato plants by azoxystrobin and Pseudomonas fluorescens. J. Plant Inter., 2(4): 233-244.

Bano, U.; Khan, A.F.; Mujeeb, F.; Maurya, N.; Tabassum, H.; Siddiqui, M.H.; Haneef, M.; Osama, K. and Farooqui, A. 2016. Effect of plant growth regulators on essential oil yield in aromatic plants. J. Chem. Pharm. Res., 8(7):733-739.

Bélanger, R.R.; Dik, A.J. and Menzies, J.G. 1998. Powdery mildews. Recent advances toward integrated control. In: Boland GJ, Kuykendall LD, eds. Plant-Microbe Interactions and Biological Control. New York, USA: Dekker, 89-109.

Chen, W.-J.; Delmotte, S.; Richard-Cervera, S.; Douence, L.; Greif, C. and CorioCostet, M.-F. 2007. At least two origins of fungicide resistance in grapevine downy mildew populations. Appl. Environ. Microbiol., 73(16): 5162-5172.

Compant, S.; Duffy, B.; Nowak, J.; Clement, C. and Barka, E.A. 2005. Use of plant growth-promoting bacteria for biocontrol of diseases: Principles, mechanisms of action, and future prospects. Appl. \& Environ. Microbiol., 71: 4951-4959.

Deore, P.B.; Sawant, D.M. and Ilhe, B.M. 2004. Comparative efficacy of Trichoderma spp. for the control of powdery mildew of cluster bean. Indian J. Agric. Res., 38(3): 212-216.

Elad Y.; Chet, I. and Henis, Y. 1981. A selective medium for improving quantitative isolation of Trichoderma spp. from soil. Phytoparasitica, 9: 59-67.

Elad, Y.; Kirshner, B.; Yehuda, N. and Sztejnberg, A. 1998. Management of powdery mildew and gray mould of cucumber by Trichoderma harzianum T39 and Ampelomyces quisqualis AQ10. BioControl, 43: 241-251.

El-Gabry, Khadiga I.M.; Sarabana, Sanaa S.H. and Abou El- Khair, Amal W. 2015. Effect of some microbial activators on onion plantlets growth quality. Middle East J. Agric. Res., 4(4): 932-937.

El-Gamal, Nadia G. 2003. Usage of some biotic and abiotic agents for induction of resistance to cucumber powdery mildew under plastic house conditions. Egypt. J. Phytopathol., 31(1-2): 129-140.

El-ghanam, A.A.; Farfour, S.A. and Ragab, S.S. 2015. Bio-suppression of strawberry fruit rot disease caused by Botrytis cinerea. Glo. Adv. Res. J. Agric. Sci., 4(8): 404-414.

El-Mougy, N.S. and Abdel-Kader, M.M. 2013. Effect of commercial cyanobacteria products on the growth and antagonistic ability of some bioagents under laboratory conditions. J. Pathogens, 2013: 1-11.

Egypt. J. Phytopathol., Vol. 47, No. 1 (2019) 
El-Morsy, S.A. and Shalaby, I.A. 2013. Control of chamomile powdery mildew disease using potassien, citrien and chitosan. J. Plant Prot. \& Path., Mansoura Univ., 4(11): 985-991.

Esterbaner, H.; Schwarzl, E. and Hayn, M. 1977. A rapid assay for catechol oxidase and laccase using 2-nitro-5-thio benzoic acid. Anal. Biochem., 77: 486-494.

Gaur, A.C.; Sadasivan, K.V.; Vimal, O.P. and Mathur, R.S. 1971. A study of decomposition of organic matter in an alluvial soil: $\mathrm{CO}_{2}$ evolution, microbiological and chemical transformation. Plant and soil, 34:17-28.

Gosztola, B. 2012. Morphological and Chemical Diversity of Different Chamomile (Matricaria recutita L.) Populations of the Great Hungarian Plain. Ph.D. Thesis, Fac. Horticult. Sci., Corvinus University of Budabest, Pp 1-16.

Guenther, E. 1961. "The Essential Oils". D. Van Norstand Inc. NY, USA. Pp 569.

Gutierrez-Manero, F.J.; Ramos, B.; Probanza, A.; Mehouachi, J. and Talon, M. 2001. The plant growth promoting rhizobacteria Bacillus pumilus and Bacillus licheniformis produce high amounts of physiologically active gibberelins. Physiol. Plant, 111: 206-211.

Hammerschmidt, R. 1999. Induced disease resistance: How do induced plants stop pathogens? Physiol. \& Mol. Plant Pathol., 55: 77-84.

Handelsman, J. and Stabb, E.V. 1996. Biocontrol of soil-borne plant pathogens. The Plant Cell, 8: 1855-1869.

Hegazi, M.A. and El-Kot, G.A. 2010. Biological control of powdery mildew on zinnia (Zinnia elegans, L) using some biocontrol agents and plant extracts. $J$. Agric. Sci., 2(4): 221-230.

Hewedy, M.A.; Rahhal, M.M.H. and Ismail, I.A. 2000. Pathological studies on soybean damping-off disease. Egypt. J. Appl. Sci., 15: 88-102.

Hussien, M.Y.; Abd-El-All, A.A.M. and Mostafa, S.S. 2009. Bioactivity of algal extracellular byproducts on cercospora leaf spot disease, growth performance and quality of sugar beet. In Proceeding of the $4^{\text {th }}$ Conference on Recent Technologies in Agriculture, Cairo, Giza, Pages 1-13.

Idris, E.E.S.; Iglesias, D.J.; Talon, M. and Borriss, R. 2007. Tryptophan-dependent production of Indole-3- Acetic Acid (IAA) affects level of plant growth promotion by Bacillus amyloliquefaciens FZB42. Mol. Plant Microbe Interact., 20: 619-626.

Joseph, L.M.; Tan, T.K. and Wong, S.M. 1998. Antifungal effect of hydrogen peroxide and peroxidase on spore germination and mycelial growth of Pseudocercospora species. Can. J. Botany, 76: 2119-2124.

Jufri, A.F.; Sudradjat and Eko Sulistyono, E. 2016. Effects of dry Spirulina platensis and antitranspirant on growth and yield of chili pepper (Capsicum annuum L.). J. Agron. Indonesia, 44(2): 170-175. 
Kemka, H.O.; Rebecca, A.A. and Gideon, O.A. 2007. Influence of temperature and $\mathrm{pH}$ bioresource and protein biosynthesis in putative Spirulina sp. Bioresource Technol., 98: 2207-2211.

Khalifa, E.Z.; El-Shenawy, Z. and Awad, H.M. 1995. "Biological control of damping-off and root-rot of sugar beet," Egypt. J. Phytopathol., 23: 39-51.

King, E.O.; Ward, M.K. and Raney, D.E. 1954. Two simple media for the demonstration of pyocyanin and fluorescein. J. Lab. Clin. Med., 44: 301-307.

Ko, H.S.; Jin, R.D.; Krishnan, H.B.; Lee, S.B. and Kim, K.Y. 2009. Biocontrol ability of Lysobacter antibioticus HS124 against Phytophthora blight is mediated by the production of 4-hydroxyphenylacetic acid and several lytic enzymes. Curr. Microbiol., 59: 608-615.

Kohl, I. and Fokkema, N.J. 1998. Strategies of biological control of necrotrophic fungal foliar pathogens. In Plant-Microbe interactions and biological control (G. Boland and L.D. Kuykendall, Eds.). Marcel Dekker, Inc., New York W. pp. 49-88.

Lewis, A.; Lumsden, R.D. and Locke, J.C. 1996. "Biocontrol of damping-off diseases caused by Rhizoctonia solani and Pythium ultimum with alginate prills of Gliocladium virens, Trichoderma hamatum and various food bases," Biocont.Sci. \& Technol., 6(2): 163-173.

Mahmoud, A.A.; Mostafa, S.S.M.; Abd El-All, A.A.M. and Hegazi, A.Z. 2007. Effect of cyanobacterial inoculation in presence of organic and inorganic amendments on carrot yield and sandy soil properties under drip irrigation regime. Egypt. J. Appl. Sci., 22(12B): 716-733.

Mohammad, S.M. 2011. Study on chammomile (Matricaria chamomilla L.) usage and farming. Adv. Env. Biol., Iran, 5(7): 1446-1453.

Newall, C.A.; Anderson, L.A. and Phillipson, J.D. 1996. Herbal medicines: A guide for health care professionals. London: Pharm. Press, ix, 296.

O'Brien, P.A. 2017. Biological control of plant diseases. Aust. Plant Pathol., Pages $1-13$.

Ongena, M.; Duby, F.; Jourdan, E.; Beaudry, T.; Jadin, V.; Dommes, J. and Thonart, P. 2005a. Bacillus subtilis M4 decreases plant susceptibility towards fungal pathogens by increasing host resistance associated with differential gene expression. Appl. Microbiol. Biotechnol., 67: 692-698.

Ongena, M.; Jacques, P.; Toure, Y.; Destain, J.; Jabrane, A. and Thonart, P. 2005b. Involvement of fengycin-type lipopeptides in the multifaceted biocontrol potential of Bacillus subtilis. Appl. Microbiol. Biotechnol., 69: 29-38.

Paulitz, T.C. and Bélanger, R.R. 2001. Biological control in greenhouse systems. Annu. Rev. Phytopathol., 39: 103-133.

Egypt. J. Phytopathol., Vol. 47, No. 1 (2019) 
Pimentel, D.; Acquay, H.; Biltonen, M.; Rice, P.; Silva, M.; Nelson, J.; Lipner, V.; Giordano, S.; Horowitz, A. and D'Amore, M. 1992. Environmental and economic costs of pesticide use. BioScience, 42(10):750-760.

Raaijmakers, J.M.; Vlami, M. and Souza, J.T. 2002. Antibiotic production by bacterial biocontrol agents. Antonie Van Leeuwenhoek 81: 537-547.

Richardson, A.E.; Barea, J.M.; McNeill, A.M. and Prigent-Combaret, C. 2009. Acquisition of phosphorus and nitrogen in the rhizosphere and plant growth promotion by microorganisms. Plant Soil, 321: 305-339.

Roberti, R.; Righini, H. and Pérez Reyes, C. 2016. Activity of seaweed and cyanobacteria water extracts against Podosphaera xanthii on zucchini. Italian J. Mycol., 45: 66-77.

Romero, D.; deVicente, A.; Rakotoaly, R.H.; Dufour, S.E.; Veening, J.W.; Arrebola, E.; Cazorla, F.M.; Kuipers, O.P.; Paquot, M. and Pérez-García, A. 2007. The iturin and fengycin families of lipopeptides are key factors in antagonism of Bacillus subtilis toward Podosphaera fusca. Mol. Plant Microbe Interact., 20(4): 430-40.

Šavikin, K.; Zdunić, G.; Menković, N.; Zivkovic, J.; Ćujić, N.; Tereščenko, M. and Bigović, D. 2013. Ethnobotanical study on traditional use of medicinal plants in South-Western Serbia, Zlatibor District. J. Ethnopharmacol., 146(3): 803810 .

Seied, N.E.; Yaegoob, R.; Amin, B.P. and Bahzad, S. 2013. Effect of chemical fertilizers and bio-fertilizers application on some morpho-physiological characteristics of forage sorghum. Intr. J. Agron. \& Plant Prod., 4(2): 223231.

Shalaby, T.A. and El Ramady, H. 2014. Effect of foliar application of bio-stimulants on growth, yield components and storability of garlic (Allium sativum L.). Australian J. Crop. Sci., 8(2): 271-275.

Shindy, W.W. and Smith, O. 1975. Identification of plant hormones from cotton extracts. Plant Physiol., 55: 550-554.

Shoda, M. 2000. Bacterial control of plant diseases. J. Biosci. Bioeng., 89: 515-521.

Singh, U.P.; Prithiviraj, B.; Singh, K.P. and Sarma, B.K. 2000. Control of powdery mildew (Erysiphe pisi) of pea (Pisum sativum) by combined application of plant growth promoting. Zeitschrit-planzenkrankheiten und Planzenschutz, 107:59-66.

Skulberg, O.M. 2000. Microalgae as a source of bioactive molecules-experience from cyanophyte research. J. Appl. Phycol., 12: 341-348.

Smitherman, L.C.; Janisse, J. and Mathur, A. 2005. The use of folk remedies among children in an urban black community: Remedies for fever, colic, and teething. Pediatrics, 115: e297-e304. 
Snedecor, G.W. and Cochran, W.G. 1989. "Statistical Methods". 8th. ed. Iowa State Univ. Press, Ames, Iowa, USA, 251 pp.

Srivastava, J.K.; Shankar, E. and Gupta, S. 2010. Chamomile: A herbal medicine of the past with bright future. Mol. Med. Report., 3(6): 895-901.

Szoke, E.; Maday, E.; Kiss, S.A.; Sonnewend, L. and Lemberkovics, E. 2004. Effect of magnesium on essential oil formation of genetically transformed and no transformed chamomile cultures. J. Am. Nut., 23: 763S-767S.

Vaishampayan, A.; Sinha, R.P.; Hader, D.P.; Dey, T.; Gupta, A.K.; Bhan, U. and Rao, A.L. 2001. Cyanobacterial biofertilizers in rice agriculture. Botanical Review, 67(4): 453-516.

Van Loon, L.C.; Bakker, P.A.H.M. and Pieterse, C.M.J. 1998. Systemic resistance induced by rhizosphere bacteria. Ann. Rev. Phytopathol., 36: 453-483.

Whipps, J.M. 2001. Microbial interactions and biocontrol in the rhizosphere. J. Exp. Bot., 52: 487-511.

Whitney, E.D.; Lewellen, R.T. and Skoyen, I.O. 1983. Reaction of sugar beet to powdery mildew: genetic variation, association among testing procedure and resistance breeding. Phytopathology, 73: 182-185.

Worthington, X.X. 1971. "Enzyme Manual", Worthington Biochemical Corp., Freehold, New Jersey, Pages 41-45.

Zaidi, S.F.; Muhammad, J.S.; Shahryar, S.; Khan, U.; Gilani, A.H.; Jafri, W. and Sugiyama, T. 2012. Anti-inflammatory and cytoprotective effects of selected Pakistani medicinal plants in Helicobacter pylori-infected gastric epithelial cells. J. Ethnopharmacol., 141(1): 403-410.

Zarrouk, C. 1966. Contribution à l'étude d'une cyanophycée: influence de divers facteurs physiques et chimiques sur la croissance et la photosynthèse de Spirulina maxima (Setch et Gardner) Geitler. Ph.D. Thesis, University of Paris, France, Pages 11-83.

Zucchi, M.R.; Oliviera Júnior, V.F.; Gussoni, M.A.; Silva, F.C. and Marques, N.E. 2013. Ethnobotanical survey of medicinal plants in Ipameri City-Goiás State. Revista Brasileira Plantas Medicinais 15(2): 273-279.

Corresponding author: Ghebrial, E.W.R.

E-mail: dr.emanwageeh@yahoo.com

(Received 24/02/2019;

in revised form 14/Apr/ 2019

Egypt. J. Phytopathol., Vol. 47, No. 1 (2019) 


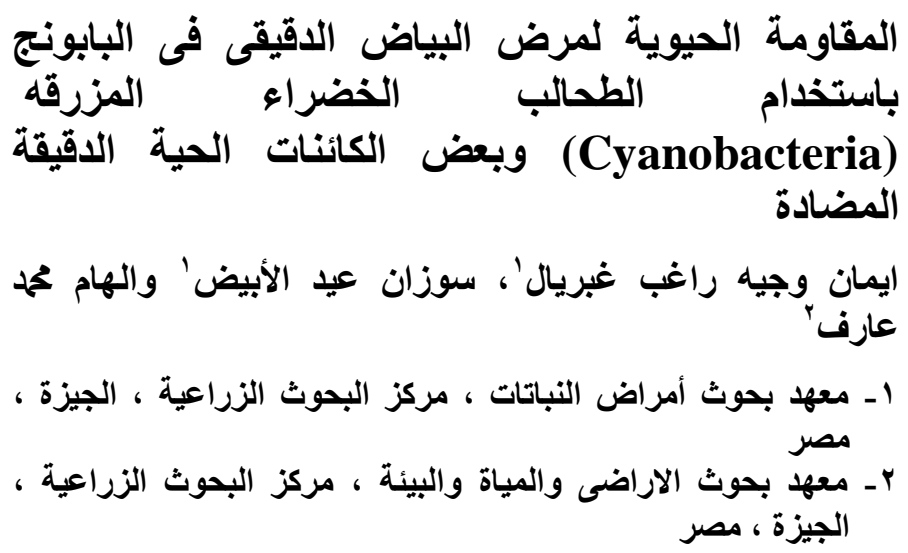

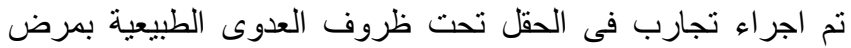

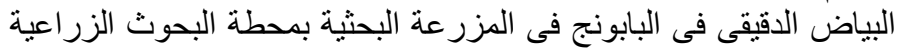

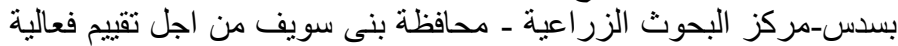

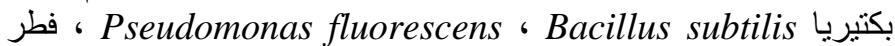

Spirulina platensis وطحلب Trichoderma harzianum

بمفردها او مختلطة فى مقاومة البياض الدقيقى وانتاجية نباتات البابونج

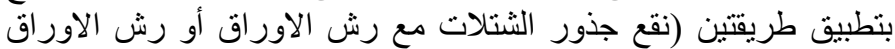

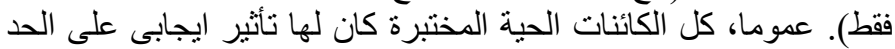

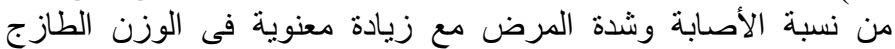

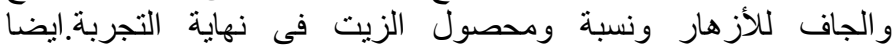

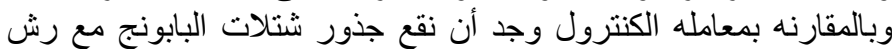

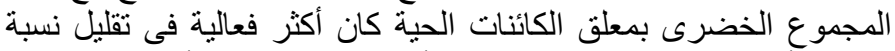

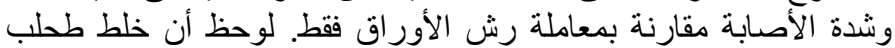

Spirulina platensis

المعاملات بمفردها. وكان أعلى تأثثر فى القطعة التجريبيه التى تم معاملتها

بخليط من S. platensis + P. fluorescens بالأضافة الى الى المبيد

الفطري توباس. علاوة على ذللك, اظهرت كل المعاملات زيادة معنوية فى الزي

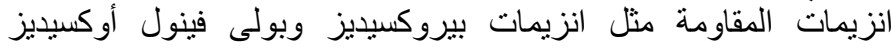

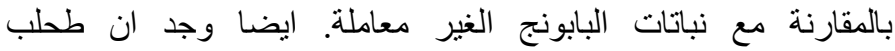

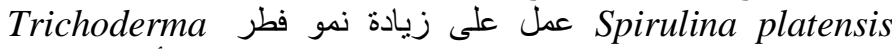

ونمو البكتريا المختبرة معنويا ولم يظهر اي تأثير مثبط لها لها

وبالتالى تحسين الحالة الميكروبية فى محيط جذور نباتات البابونج. 